\title{
膜ファウリング特性の簡易評価に基づく濾過挙動の推算
}

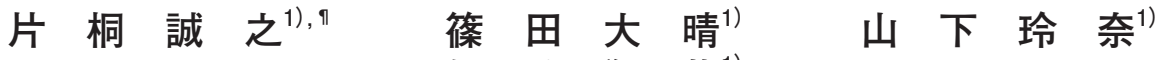 \\ 福 地 翔 哉 ${ }^{1}$
}

\section{Estimation of Filtration Behavior Based on Simplified Evaluation of Membrane Fouling Characteristics}

\author{
Nobuyuki KATAGIRI ${ }^{1), ~}{ }^{\text {, Taisei SHINODA }}{ }^{1)}$, Reina YAMASHITA ${ }^{1)}$ and Shoya FUKUCHI ${ }^{1}$ \\ 1) Department of Environmental Technology, Meijo University, 1-501 Shiogamaguchi, Tempaku-ku, Nagoya 468-8502, Japan
}

\begin{abstract}
We propose a method of estimating the overall behavior of filtration using the fouling index obtained from limited membrane filtration data. The blocking index and plugging constant required for estimating filtration behavior were determined from the fouling mechanism index (FMI) with the aid of the blocking filtration law. The calculated data of the variation over time of the flux decline using the blocking index, plugging constant, and membrane properties were in reasonable agreement with experimental data. It was confirmed that this method can be widely applied to estimate membrane filtration behavior regardless of filtration conditions, such as sample concentration and the type of membrane, and fouling mechanisms, such as membrane pore blocking and cake formation. The calculated data of filtration behavior obtained from the membrane properties and FMI are useful because they can be used to determine the timing of membrane cleaning and membrane replacement.
\end{abstract}

Keywords: Membrane filtration; Membrane fouling; Fouling index; Fouling mechanism; Blocking filtration

\section{1.はじめに}

浄水処理や下水処理，あるいは海水淡水化などにおい て, 膜を用いる水処理技術が導入されつつある1)。設置 面積が小さい，微粒子や微生物細胞なども確実に除去さ れ高度な処理水質が期待できるなど様々なメリットがあ るものの, 膜ファウリングによる処理性能低下が, 更な る普及に向けて解決すべき課題の一つとして挙げられて いる。膜ファウリングは, 水処理膜による滤過操作で, 液中の懸濁粒子や溶質が膜の表面や内部で捕捉されるこ とにより生じ, 液の流れが妨げられるため滤過抵抗が増 大する。その結果, 定圧操作で滤過を行っている場合は 滤過速度が減少, 定速操作では滤過圧力が上昇すること になる2,3)。滤過を続けることで, 滤過抵抗は徐々に大き くなり，やがて滤過の継続が非効率あるいは困難となる ため, 膜の洗浄や交換が必要となる。したがって, 膜つ アウリングの進行を簡便に評価し, 滤過抵抗増大の挙動 を推測することができれば，膜による水処理プロセスの 効率化に極めて有用である。

膜ファウリングを評価するファウリング指標として, SDI (Silt Density Index) や MFI (Modified Fouling Index）が提案されている。SDIは，ASTM D4189-074)
において, 直径 $47 \mathrm{~mm}$, 平均孔径 $0.45 \mu \mathrm{m}$ の親水性の MCE 膜 (Mixed cellulose nitrate and cellulose acetate) を用いて, 濾過圧力 $207 \mathrm{kPa}$ で濾過を行い，開始から 500 $\mathrm{mL}$ の試料液を濾過するのに要する時間 $t_{1}$ と, 開始 15 分 後（試料液性状によって変更可）から $500 \mathrm{~mL}$ の試料液を 濾過するのに要する時間 $t_{2}$ から, SDI = $100\left(1-t_{1} / t_{2}\right) / 15$ により求めることが定められている。これは, 滤過の継 続により同量の試料液を濾過する時間が長くなる様子を, 膜ファウリング指標として表している。簡便な評価法で あることから広く用いられているが，測定に使用する膜 の種類と孔径が限定され，SDI 值が濁質や溶質の濃度に 比例しないこともあり，また理論的な裏付けがないこと なども問題点として指摘されている ${ }^{5 \sim 10)}$ 。 $\mathrm{MFI}^{11)}$ は, 平 均孔径 $0.45 \mu \mathrm{m}$ の精密滤過膜を用いて定圧条件で試験さ れ, ケーク滤過理論に基づき, 滤過速度の逆数と滤液量 の関係を表すグラフの傾きから求められる。ファウリン グの程度を表すことができるが，SDIのような限られた 期間のデー夕のみで評価することはできないため，連続 的な滤過データが必要となる。また, 膜面上にケークが 形成されず，膜の目詰まりが生じる場合の滤過挙動には 適用が難しい。より小さな粒子に扔いても妥当な值が得 られるように, 限外滤過膜やナノ滤過膜を用いる

1 ）名城大学理工学部環境創造工学科 $\bar{T} 468-8502$ 名古屋市天白区塩釜口 1-501

ๆ＼cjkstart連絡先：katagiri@meijo-u.ac.jp 
MFI-UF ${ }^{12)}$ や MFI-NF ${ }^{13)}$ が提案されている。いずれのフ アウリング指標にも長所と短所があり，様々な要望に応 えられる理想的な指標がないことから, より有用性が高 く，簡便に測定することができる新たな膜ファウリング 指標の開発が望まれている。

最近, 限られた滤過速度の減衰データから膜ファウリ ングの機構と程度を個別に判定する二つの指標 FMI (Fouling Mechanism Index) と FDI (Fouling Degree Index）が提案された ${ }^{14)}$ 。FMI と FDI は, SDI と同様に 限られた期間の濾過データのみで評価可能であるが，使 用する膜や濾過圧力は限定されず任意で, 一定時間に得 られる滤液量の変化から求められる。対象とする濾過デ 一夕を, 濾過時間ではなく, 滤液量にすることで滤過理 論が適用できるようになり, SDI とは異なり理論的裏付 けが与えられ, 濾過挙動の推算にも繋がる。FMIには, 閉塞濾過理論が適用され, 使用する膜の透過特性と閉塞 特性が条件を満たすと, 閉塞特性值との関係を表す理論 式が得られ，ファウリング機構のみを評価することがで きる。一方, FDIには, ケーク濾過理論が適用され, 一 定時間に得られる濾液量の変化の仕方からファウリング の程度のみが評価される。いずれの指標も実際に用いる 試料, 膜, 圧力で測定することができ, 粒子（カオリン, ベントナイト, PMMA, シリカ), 高分子 (アルギン酸 ナトリウム，デキストラン，ポリエチレングリコール， BSA), 混合物（ウーロン茶, 緑茶) で有用性が確認さ れている。

FMI は, 值の求め方が容易で, 利用のしやすさにおい て FDI より優位性があるが, 膜ファウリング機構のみを 表す指標として提案されている ${ }^{14)}$ 。すなわち, FMI では ファウリングがどの程度進行しているかを評価する
ことはできない。これは理論式を導出する際に，条件 $\left(k(\mathrm{~d} v / \mathrm{d} t)_{0}{ }^{2-n}(2-n) T>>1\right.$, 各記号の説明は後述する) が設定されているためである ${ }^{14)}$ 。したがって，設定条件 を満たしていない場合には，ファウリング機構だけでな くファウリングの程度も值に影響を及ぼすことになり， 理論式による解析ができないものと考えられるが，この ことについては明らかとなっていない。条件にとらわれ ず，理論式が適用できない場合においても，シンプルな 計算で FMI 值から濾過挙動を推算する手法が確立されれ ば，膜ファウリング指標 FMI の有用性をさらに高めるこ とができる。そこで本研究では, 廃水処理污泥や海水中 から検出され, 数多くの膜ファウリング研究でモデルフ アウラントとして用いられているアルギン酸ナトリウ $ム^{15 \sim 19)}$ を試料とし, 試料濃度 3 条件, 分離膜 3 種類で膜 滤過試験を行い, FMI 值と膜閉塞特性值との関係を明ら かにすることで, 滤過全体の挙動を推算できる新たな手 法を提案し，その妥当性を検証する。

\section{2. 方法}

\section{1 濾過試料}

試料液には，アルギン酸ナトリウム（SA：Sodium Alginate, 分子量 129,000 , ナカライテスク）の水溶液を 用いた。アルギン酸ナトリウムを, 超純水製造システム (Elix-UV20 および Milli-Q Advantage, ミリポア) で得 た超純水に溶解させ, 濃度 $C=25,50,100 \mathrm{mg} \mathrm{L}^{-1}$ のア ルギン酸ナトリウム水溶液を調製した。溶液の $\mathrm{pH}$ は, 6.5 程度であった。

\section{2 濾過装置}

滤過試験は, Fig. 1 に示す滤過システムを用い, 窒素 ガスによる加圧濾過を行った。電子レギュレータで濾過

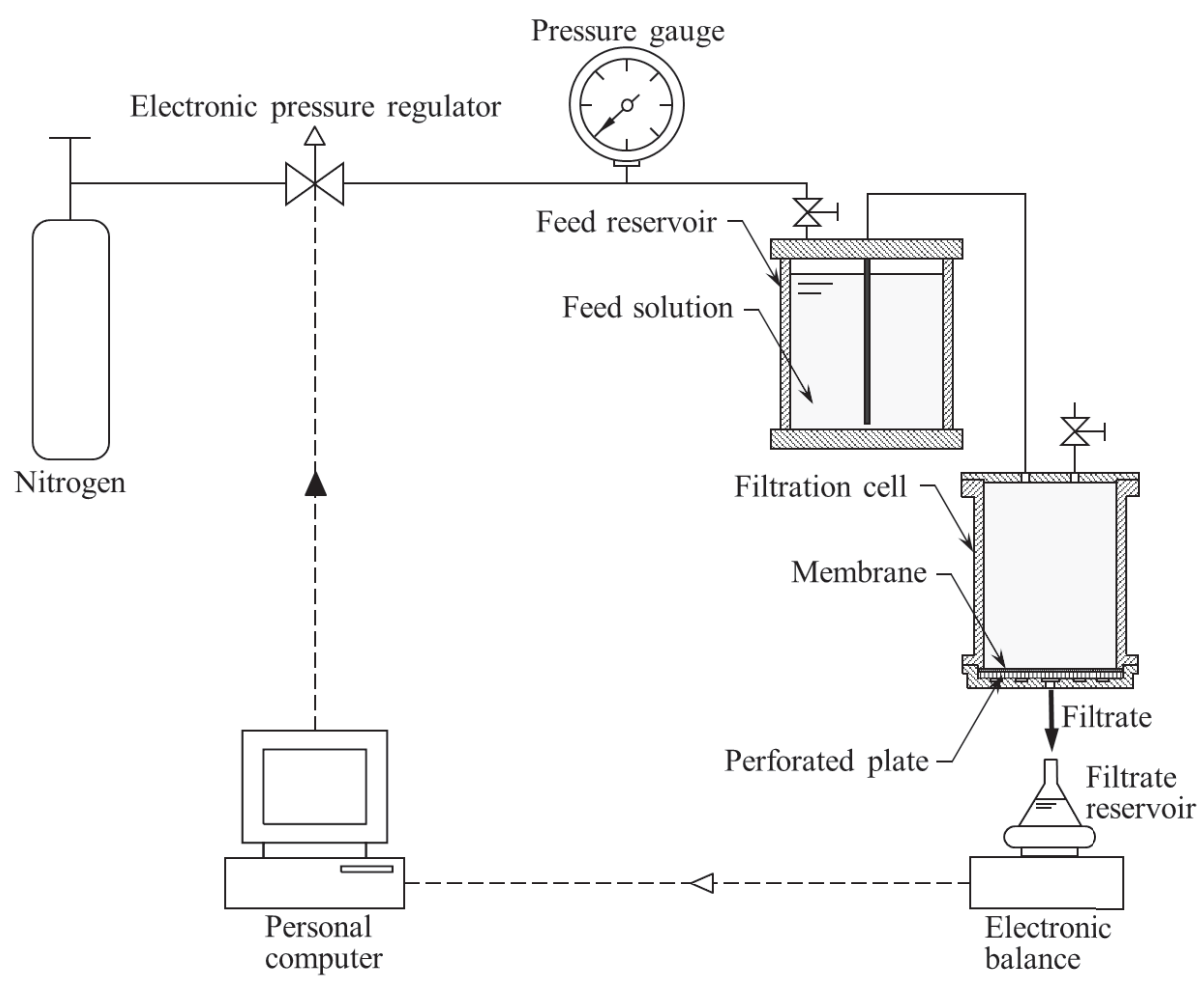

Fig. 1 Schematic of the apparatus for membrane filtration test. 
圧力を $50 \mathrm{kPa}$ に保ち, 濾液量の経時変化を電子上血天 秤により測定した。滤過器の滤過面積は $9.35 \mathrm{~cm}^{2}$, 試料 液タンク（RP-1，アドバンテック）の容量は $1 \mathrm{~L}$ である。 分離膜には, 公称孔径 $d_{\mathrm{m}}=0.1 \mu \mathrm{m}$ の 2 種類の精密濾過 (MF) 膜; Polyvinylidene Difluoride（親水性 PVDF, メ ルクミリポア）膜と Mixed Cellulose Ester (MCE，ア ドバンテック）膜, および分画分子量 $10 \mathrm{kDa}$ の限外濾 過 (UF) 膜; 再生セルロース（ウルトラセル-PL, メル クミリポア）膜を用いた。

\section{3. 結果および考察}

\section{1 膜ファウリング指標 FMI（Fouling Mechanism Index)}

膜ファウリング指標 FMI は，二つの滤過期間における 濾液量の比から求められる ${ }^{14)}$ 。FMI を決定するための時 間設定は任意とされているので, 滤過開始後 $T(=10$ $\min )$ から $t_{0}(=5 \mathrm{~min})$ で採取される濾液量 $V_{\mathrm{i}}$, および 濾過開始後 $\left(T+t_{\mathrm{t}}\right)\left(t_{\mathrm{t}}=15 \mathrm{~min}\right)$ から同じ $t_{0}(=5 \mathrm{~min})$ で採取される濾液量 $V_{\mathrm{f}}$ から FMI を求めることとした。 Fig. 2 は, 膜濾過を行った際の 5 分ごとの滤液量の変化 で, ○で示した $10 \mathrm{~min}$ から $15 \mathrm{~min}$ までの濾液量 $V_{\mathrm{i}}=$ $21.9 \mathrm{~cm}^{3}$ と $25 \mathrm{~min}$ から $30 \mathrm{~min}$ までの濾液量 $V_{\mathrm{f}}=11.7$ $\mathrm{cm}^{3}$ を式(1) に代入することにより FMI = $3.10 \mathrm{~min}^{-1}$ が 求まる。したがって, 濾液量の経時変化を連続的に測定 する必要はなく，任意の時間からの 5 分間といった限ら れた期間に採取した濾液量を測定すればよい。なお，濾 過開始直後から濾液を採取しないのは, 特に新品の膜を 用いた場合, 濾過初期における閉塞挙動が複雑となるこ とが多く, 濾過機構との関係を評価するのが難しくなる からである。計測開始時間 $T$ の設定は, 挙動の安定性と 計測に要する時間を考慮して決定することが望ましく, 本研究における $T=10 \mathrm{~min}$, 計測終了時間 $30 \mathrm{~min}$ は適 度な時間であると考える。

$$
\mathrm{FMI}=\frac{100}{t_{\mathrm{t}}}\left(1-\frac{V_{\mathrm{f}}}{V_{\mathrm{i}}}\right)
$$

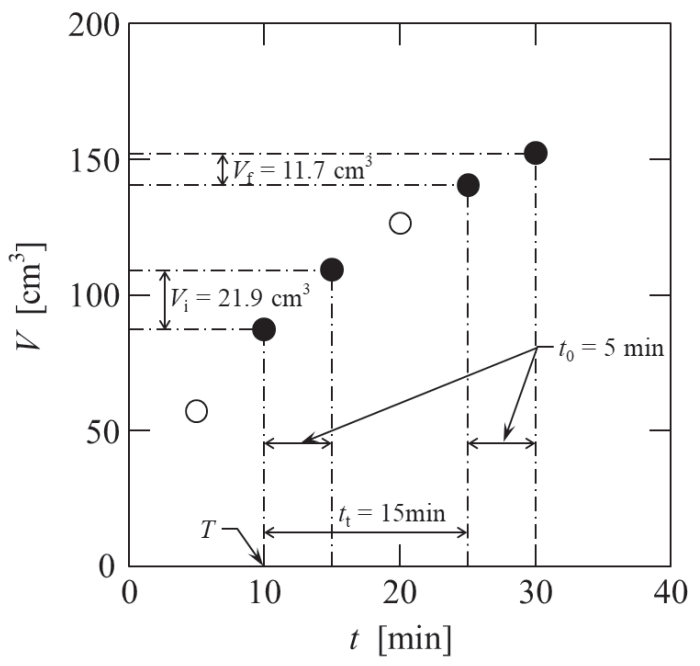

Fig. 2 Typical membrane filtration data in dead-end constant pressure filtration.

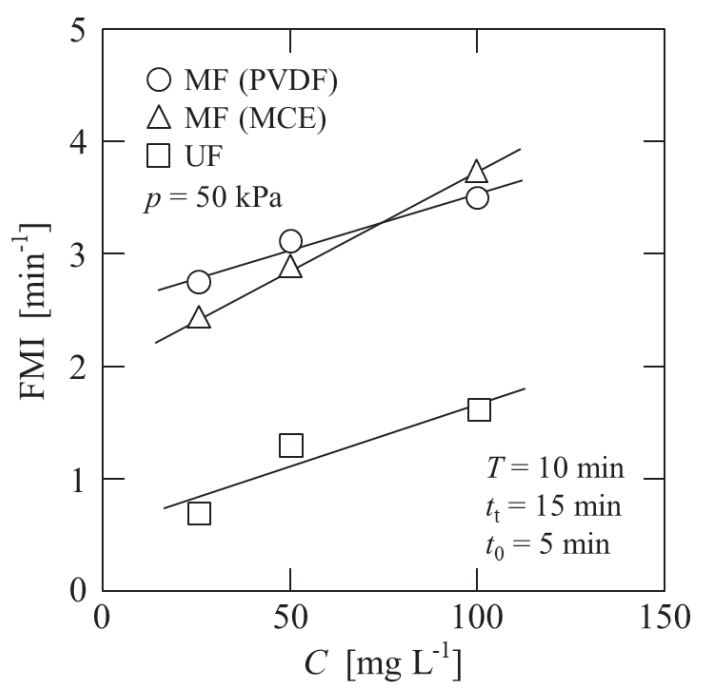

Fig. 3 Relationship between FMI and solute concentration $C$.

試料液の濃度 $C$ を変化させて, 種々の分離膜で膜滤過 を行ったときの, FMI とCとの関係を Fig. 3 にプロッ トした。試料濃度が大きくなると膜ファウリングが生じ やすくなり，いずれの分離膜においても濃度 $C$ に比例し て FMI 值が大きくなることが確認された。これは濃度増 大による膜ファウリングの進行を FMI で評価できること を示している。また，図からは，膜によって同一試料に よるファウリングの程度や濃度増大にともなうファウリ ングの進行が異なることが明らかである。特に, 溶質が 膜を透過する $\mathrm{MF}$ 膜と, 溶質が全阻止され膜面上に堆積 するUF膜とでは, FMI 值に顕著な差が認められ, UF 膜の方が值が小さくなった。入谷ら ${ }^{14)}$ が示したように FMI はファウリング機構に大きく影響されるものと推察 され, 膜種が異なる場合は值の大きさのみでファウリン グの程度を評価することはできない。

\section{2 閉塞濾過挙動の解析}

濾材の閉塞を記述するモデルとして, Hermans と Bredée $^{20)}$ により提案され, Grace ${ }^{21)}$ により体系化された 閉塞濾過モデルがある ${ }^{22,23)}$ 。閉塞濾過モデルにおける定 圧条件での特性式として次式が提案されており, 膜閉塞 濾過挙動の解析にも用いられている

$$
\frac{\mathrm{d}^{2} t}{\mathrm{~d} v^{2}}=k\left(\frac{\mathrm{d} t}{\mathrm{~d} v}\right)^{n}
$$

ここで, $t$ : 濾過時間 $(\mathrm{s}), v$ : 単位濾過面積あたりの濾 液量 $(\mathrm{m}), \mathrm{d} t / \mathrm{d} v$ : 濾過速度の逆数 $\left(\mathrm{s} \mathrm{m}^{-1}\right), k$ : 定数 $\left(\mathrm{s}^{1-n} \mathrm{~m}^{n-2}\right), n$ : 定数 (-) である。モデルにおいて $n$ は 閉塞機構を表すものであり，2（完全閉塞），1.5（標準閉 塞), 1 (中間閉塞), 0 (ケーク濾過) のいずれかの值と なる ${ }^{3)}$ 。濾過速度の逆数 $\mathrm{d} t / \mathrm{d} v$ は, 滤過抵抗の指標と見 なすことができるため, 式(2) は膜閉塞の進行による滤 過抵抗の増加の程度を表している。滤過デー夕を連続的 に測定している場合は, 式(2) に基づいた閉塞挙動の解 析が可能となる。

Fig. 4 には, 滤過速度の逆数 $\mathrm{d} t / \mathrm{d} v$ を $v$ で微分した $\mathrm{d}^{2} t / \mathrm{d} v^{2}$ と $\mathrm{d} t / \mathrm{d} v$ との両対数プロットを示す。溶質の SA が膜細孔内に侵入して捕捉され閉塞が生じると推察され 
(a)

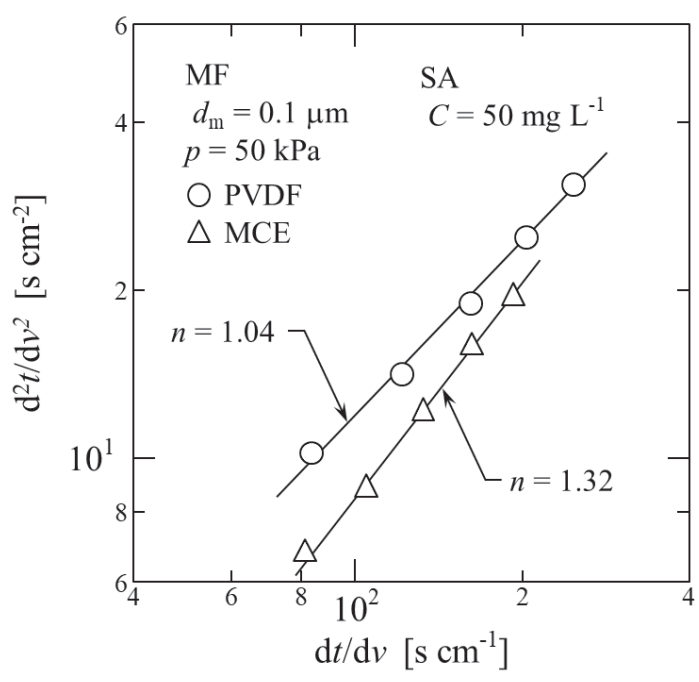

(b)

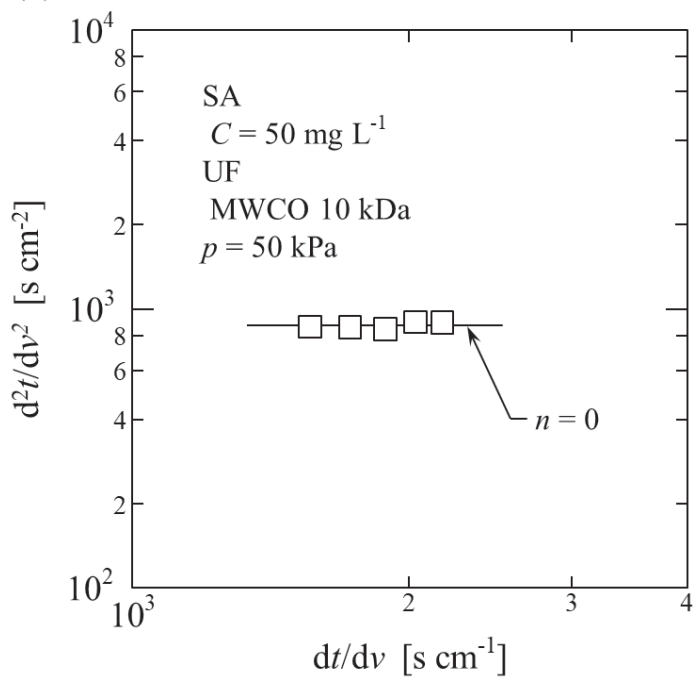

Fig. 4 Blocking filtration characteristic curve based on Eq. (2).

る $\mathrm{MF}$ 膜の場合, 孔径 $d_{\mathrm{m}}=0.1 \mu \mathrm{m}$ の PVDF 膜で $C=50$ $\mathrm{mg} \mathrm{L}^{-1}$ の SA 溶液を滤過したときの結果は, Fig. 4（a） に示すようにプロットが右上がりの直線状となり, 直線 近似により $n=1.04, k=0.100 \mathrm{~s}^{1-n} \mathrm{~cm}^{n-2}$ が得られた。分 離膜に $d_{\mathrm{m}}=0.1 \mu \mathrm{m}$ の $\mathrm{MCE}$ 膜を用いた場合にも右上が りの直線状となり, $n=1.32, k=0.0186 \mathrm{~s}^{1-n} \mathrm{~cm}^{n-2}$ であ った。一方, 膜表面で SA が全阻止されると推察される UF 膜（MWCO 10,000）を用いた場合には，Fig. 4（b） に示すようにプロットはほぼ一定の $\mathrm{d}^{2} t / \mathrm{d} v^{2}$ 值となり, $n$ $=0, k=868 \mathrm{~s} \mathrm{~cm}^{-2}$ が得られた。 $n$ が 0 となることから, 閉塞滤過モデルでは膜面上に滤過ケークが形成されるケ 一ク濾過に分類される ${ }^{3)}$ 。なお, PVDF 膜の $n=1.04$ お よび MCE 膜の $n=1.32$ は, 閉塞滤過モデルでは規定さ れていない值であるが, 式(2) の根拠を Kozeny-Carman 式に求め, 膜細孔内での粒子捕捉による空隙率と比表面 積の変化を考慮したモデルでは, nの取り得る值に制限 がないことが示されている ${ }^{24)}$ 。溶質の SA の大きさから, $\mathrm{MF}$ 膜と UF 膜とでは膜閉塞機構が大きく異なることが
推察され，解析結果はこの相違を明確に示している。ま た，同じMF 膜に分類される PVDF 膜と MCE 膜におい ても, 両者の間には閉塞特性値の $n$ と $k$ に相違があり, 膜材質や膜構造の違いが表れている。膜構造がほぼ同じ で, 表面特性の異なる親水性 PVDF 膜と疎水性 PVDF 膜 との比較では, $n$ 值は同程度, $k$ 值は疎水性 PVDF 膜の 方が大きいといった結果が得られており ${ }^{25)}$ ，膜特性と閉 塞特性值との間に相関性があることが推察される。

\section{3 濾過挙動の推算}

膜ファウリング指標 FMI は限られた期間に採取した濾 液量で評価できるのに対し, 閉塞特性值を得るための解 析には連続的に測定した滤過デー夕が必要となる。FMI と閉塞特性值 $n$ および $k$ との関係がわかれば，限られた 期間のデータのみで簡便に閉塞滤過挙動を推算すること ができる。式(2) の閉塞特性式を積分すると滤過速度を 記述する次式が得られる ${ }^{26)}$ 。

$$
\begin{aligned}
& \frac{\mathrm{d} t}{\mathrm{~d} v}=\left\{\left(\frac{\mathrm{d} t}{\mathrm{~d} v}\right)_{0}^{1-n}+k(1-n) v\right\}^{1 /(1-n)} \text { for } n \neq 1 \\
& \frac{\mathrm{d} t}{\mathrm{~d} v}=\left(\frac{\mathrm{d} t}{\mathrm{~d} v}\right)_{0} \exp (k v) \quad \text { for } n=1
\end{aligned}
$$

ここで, $(\mathrm{d} t / \mathrm{d} v)_{0}$ ：滤過初速度の逆数 $\left(\mathrm{s} \mathrm{m}^{-1}\right)$ である。 また，式(3）および（4）を積分することで滤液量 $V$ と 滤過時間 $t$ の関係を記述する次式が得られる ${ }^{14)}$ 。

$$
\begin{aligned}
& V=\frac{A}{k\left(\frac{\mathrm{d} v}{\mathrm{~d} t}\right)_{0}^{1-n}(1-n)} \cdot \\
& \quad\left[\left\{k\left(\frac{\mathrm{d} v}{\mathrm{~d} t}\right)_{0}^{2-n}(2-n) t+1\right\}^{\frac{1-n}{2-n}}-1\right] \text { for } n \neq 1,2 \\
& V=\frac{A}{k} \ln \left\{k\left(\frac{\mathrm{d} v}{\mathrm{~d} t}\right)_{0} t+1\right\} \quad \text { for } n=1 \\
& V=\frac{A}{k}\left(\frac{\mathrm{d} v}{\mathrm{~d} t}\right)_{0}\{1-\exp (-k t)\} \quad \text { for } n=2
\end{aligned}
$$

ここで, $A$ : 滤過面積 $\left(\mathrm{m}^{2}\right)$ である。FMI の定義より, 濾過開始後 $T$ から $t_{0}$ で採取される濾液量 $V_{\mathrm{i}}$ は式(5) に より次のように表すことができる。

$$
\begin{aligned}
V_{\mathrm{i}}= & \frac{A}{k\left(\frac{\mathrm{d} v}{\mathrm{~d} t}\right)_{0}^{1-n}(1-n)} \\
& {\left[\left\{k\left(\frac{\mathrm{d} v}{\mathrm{~d} t}\right)_{0}^{2-n}(2-n)\left(T+t_{0}\right)+1\right\}^{\frac{1-n}{2-n}}\right.} \\
& \left.-\left\{k\left(\frac{\mathrm{d} v}{\mathrm{~d} t}\right)_{0}^{2-n}(2-n) T+1\right\}^{\frac{1-n}{2-n}}\right]
\end{aligned}
$$

また, 滤過開始後 $\left(T+t_{\mathrm{t}}\right)$ から $t_{0}$ で採取される濾液量 $V_{\mathrm{f}}$ は次式で表すことができる。 


$$
\begin{aligned}
V_{\mathrm{f}}= & \frac{A}{k\left(\frac{\mathrm{d} v}{\mathrm{~d} t}\right)_{0}^{1-n}(1-n)} \\
& {\left[\left\{k\left(\frac{\mathrm{d} v}{\mathrm{~d} t}\right)_{0}^{2-n}(2-n)\left(T+t_{\mathrm{t}}+t_{0}\right)+1\right\}^{\frac{1-n}{2-n}}\right.} \\
& \left.-\left\{k\left(\frac{\mathrm{d} v}{\mathrm{~d} t}\right)_{0}^{2-n}(2-n)\left(T+t_{\mathrm{t}}\right)+1\right\}^{\frac{1-n}{2-n}}\right]
\end{aligned}
$$

式（8）と（9）を式(1) に代入すると, FMI の定義式は 次式となる。

$$
\begin{aligned}
& \mathrm{FMI}=\frac{100}{t_{\mathrm{t}}} \text {. } \\
& {\left[1-\frac{\left\{k\left(\frac{\mathrm{d} v}{\mathrm{~d} t}\right)_{0}^{2-n}(2-n)\left(T+t_{\mathrm{t}}+t_{0}\right)+1\right\}^{\frac{1-n}{2-n}}-}{\left\{k\left(\frac{\mathrm{d} v}{\mathrm{~d} t}\right)_{0}^{2-n}(2-n)\left(T+t_{0}\right)+1\right\}^{\frac{1-n}{2-n}}-}\right.} \\
& \left.\frac{\left\{k\left(\frac{\mathrm{d} v}{\mathrm{~d} t}\right)_{0}^{2-n}(2-n)\left(T+t_{\mathrm{t}}\right)+1\right\}^{\frac{1-n}{2-n}}}{\left\{k\left(\frac{\mathrm{d} v}{\mathrm{~d} t}\right)_{0}^{2-n}(2-n) T+1\right\}^{\frac{1-n}{2-n}}}\right]
\end{aligned}
$$

ここで, $t_{\mathrm{t},} T, t_{0}$ は設定時間であり, $(\mathrm{d} v / \mathrm{d} t)_{0}$ は濾過初 速度で，用いる分離膜によって決まる值である。したが って, FMI は閉塞濾過の特性值である $n$ と $k$ に依存する ことがわかる。

なお, $k(\mathrm{~d} v / \mathrm{d} t)_{0}{ }^{2-n}(2-n) T>>1$ のとき, FMI は次式 で表すことができる ${ }^{14)}$ 。

$$
\mathrm{FMI}=\frac{100}{t_{\mathrm{t}}}\left(1-\frac{\left(T+t_{\mathrm{t}}+t_{0}\right)^{\frac{1-n}{2-n}}-\left(T+t_{\mathrm{t}}\right)^{\frac{1-n}{2-n}}}{\left(T+t_{0}\right)^{\frac{1-n}{2-n}}-T^{\frac{1}{2-n}}}\right)
$$

$t_{\mathrm{t},} T, t_{0}$ は設定時間であるため, 式(11) で定義される FMI はファウリング機構を表す閉塞特性值 $n$ のみに依存 する。したがってFMI と $n$ は 1 対 1 の関係にあるが, Fig. 3 に示したように FMI がファウリングの程度にも影響さ れる場合には， $n$ 值が同じ，すなわちファウリング機構 が同じでも異なる FMI 值を取り得ることが考えられる。

ここで，FMI と閉塞特性值との関係を実験結果に基づ いて検討する。同じ分離膜を用いて, 溶質の濃度を変化 させた場合の閉塞濾過挙動を式(2) に基づいて解析する と, $n$ 值がほぼ同じ值になるという特徵的な結果が得ら れた。Fig. 3で示した各条件における FMI と, 閉塞特性 值 $n$ との関係を Fig. 5 に示す。 3 種類のいずれの分離膜 においても, プロットは縦方向に変化しており, 溶質濃 度により FMI は変化するが，ファウリング機構を表す $n$ 值は一定と見なすことができる。すなわち, 用いる分離 膜によって $n$ 值は決まり, FMI は $k$ 值に依存すると考え ることができる。なお，いずれの膜濾過においても，条 件 $\left(k(\mathrm{~d} v / \mathrm{d} t)_{0}^{2-n}(2-n) T>>1\right)$ は満たされていなかった。

分離膜ごとに $n$ 值が既知であるならば，FMI から閉 塞特性值 $k$ を求めることができる。FMI 值と $t_{\mathrm{t}, ~} T, t_{0}$, $(\mathrm{d} v / \mathrm{d} t)_{0}, n$ の各值を式 (10) に代入して求めた $k$ 值と溶

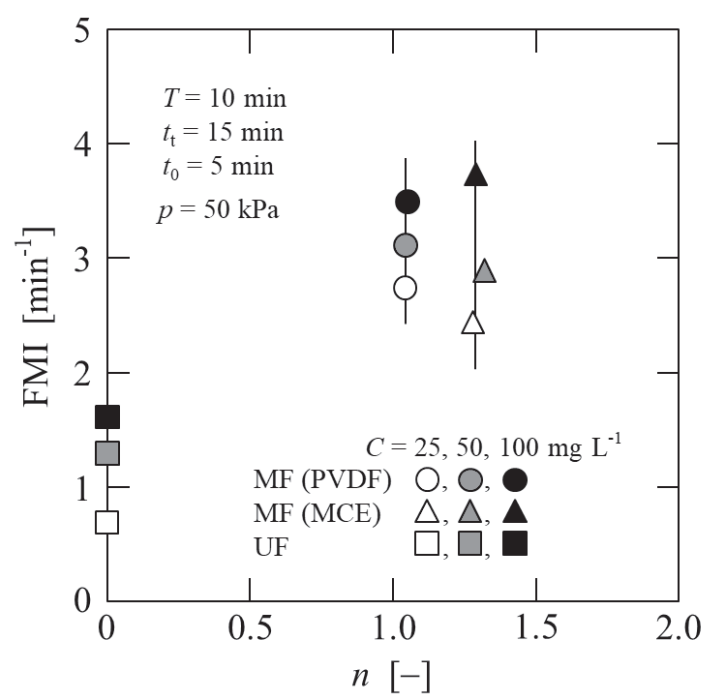

Fig. 5 Relationship between FMI and $n$ in Eq. (2).

質濃度 $C$ との関係を Fig. 6 に示す。 $n=1.04$ とした PVDF 膜と $n=1.29$ とした MCE 膜 (Fig. 6 (a)), およ び $n=0$ とした UF (Fig. 6 (b) ) 膜とも, $k$ と $C$ との間 には比例関係が認められ, FMI と同様に溶質濃度により $k$ が定まるものと考えられる。ただし, 膜閉塞機構が異 なる MF 膜と UF 膜では, $k$ 值にオーダーの異なる大き な相違が認められた。

以上のような手順で，連続的に測定した濾過データが なくても膜ファウリング指標 FMI から閉塞特性值を求め ることが可能である。ここでは, 本手法で決定した $n$ と $k$ の妥当性を検証するため, 得られた值を式(3) あるい は（5）に代入して求めた計算值と実験データの比較を行 った。Fig. 7 は, PVDF 膜を用いて 3 種類の溶質濃度の 試料を濾過した時の濾過速度の経時変化で, 式(3) に基 づいて滤過速度の逆数 $(\mathrm{d} t / \mathrm{d} v)$ と単位滤過面積あたりの 滤液量 $v$ との関係を示している。実線で示した計算值は, プロットの実験值の挙動をよく表している。Fig. 8 は, 濾液量の経時変化で, Fig. 7 に示したPVDF 膜に加えて $\mathrm{MCE}$ 膜と UF 膜のデータも示している。いずれの条件に おいても実験值の挙動を式(5) に基づく計算值で記述で きている。したがって，FMI を測定することで閉塞特性 值が求まり, 濾過全体の挙動が推算可能となることから, 膜の洗浄や交換の時期の決定にも応用できるものと期待 され，本手法の有用性は明らかである。なお，本手法は 逆洗後の膜にも適用できるものと考えられ，この場合に は逆洗で取り除けない不可逆ファウリングの影響が滤過 初速度 $(\mathrm{d} v / \mathrm{d} t)_{0}$ に表れること，またファウリング機構を 示す $n$ 值が逆洗の前後でどのように変化するのかを調べ ておくことが重要となる。FMI 值や閉塞特性值から, 膜 ファウリングを可逆ファウリングと不可逆ファウリング に区別することはできないが，ごくわずかな膜滤過デー 夕で求まる指標から濾過の全挙動を推算できるという点 に提案手法の意義があると考える。

4. まとめ

膜ファウリングの進行を簡易的な方法で評価し, 濾過 挙動の推算に繋げる手法について検討を行った。限られ 
(a)

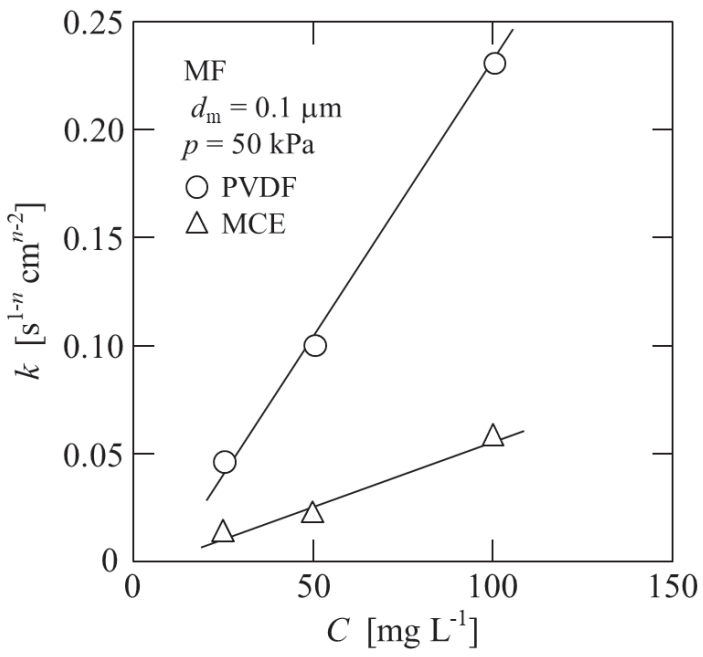

(b)

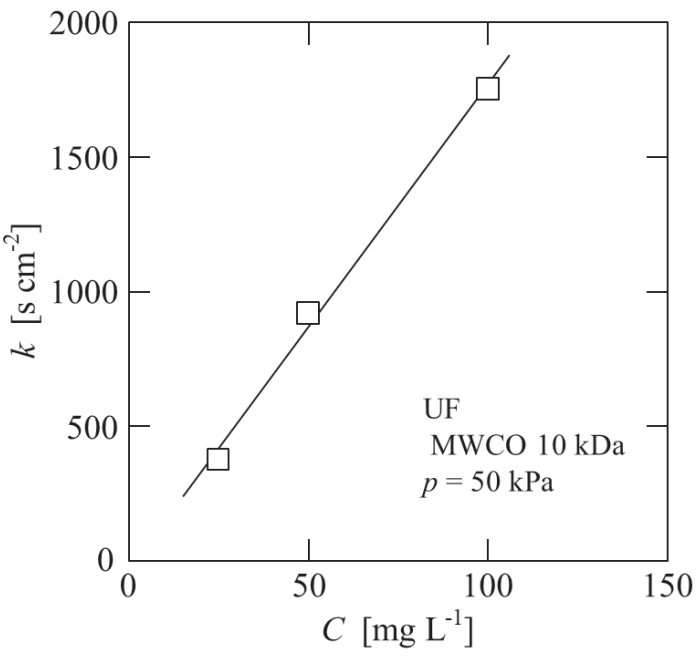

Fig. 6 Relationship between $k$ in Eq. (2) and solute concentration $C$.

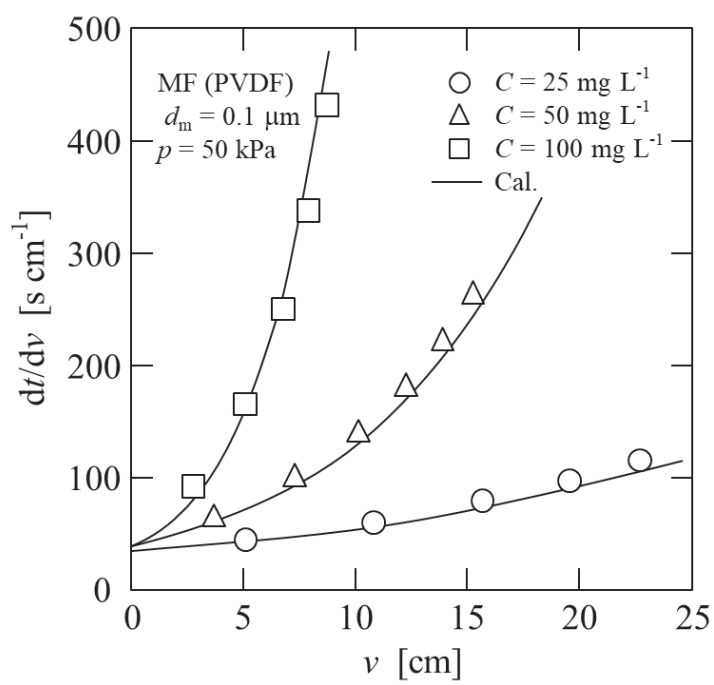

Fig. 7 Evaluation of flux decline behaviors calculated on basis of FMI.

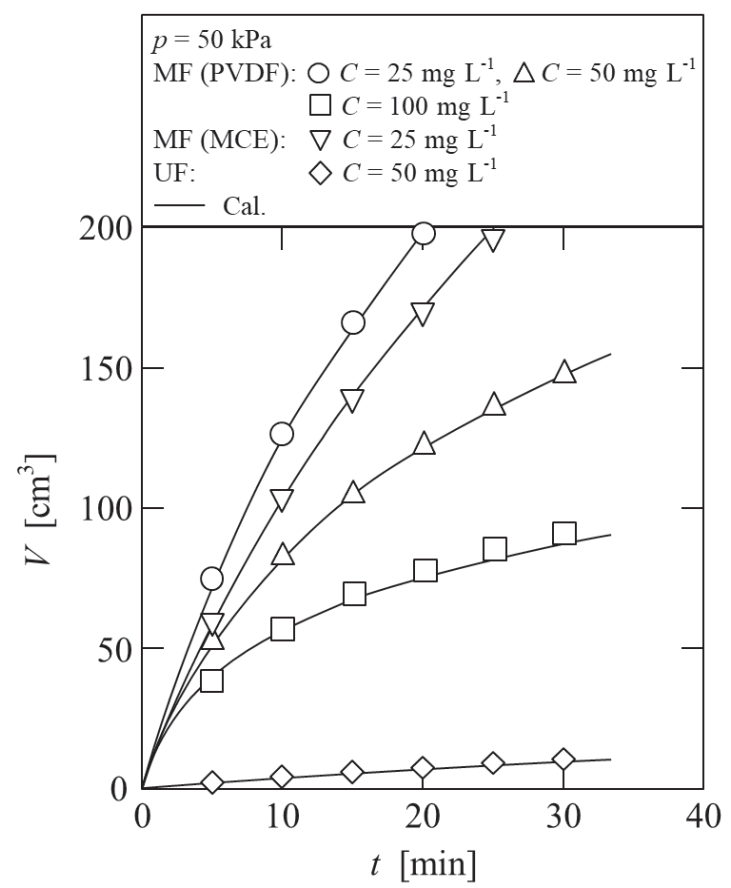

Fig. 8 Evaluation of relationship between filtrate volume and filtration time calculated on basis of FMI.

た期間のごくわずかな濾過データで評価できる膜ファウ リング指標 FMI を用い, 閉塞濾過理論の適用により，膜 の閉塞挙動の記述に必要不可欠な特性值を求める方法を 確立した。本手法は，アルギン酸ナトリウムをモデル試 料として用い, 試料濃度 3 条件, 分離膜 3 種類で検討し た結果，いずれの条件にも適用可能で，使用する膜の特 性の把握により, 詳細な濾過データがなくても容易に滤 過全体の挙動を推算できることを明らかにした。限られ たわずかな期間に採取した濾液量の変化のみで, 滤過速 度が急激に減少するまでの滤過時間が推測でき, 膜洗浄 や膜交換の時期の決定にも繋がることから，本提案手法 は周期逆洗型膜濾過プロセスの容易かつ効率的な運転に 貢献できるものと考える。

謝 辞

本研究の一部は, 令和 2 年度文部省科学研究費（基盤 研究 (C), 17K06889 および 20K05190）の援助を受けて 行われたことを記して感謝の意を表する。

(原稿受付 2021 年 3 月 19 日)

（原稿受理 2021 年 5 月 17 日）

\section{参 考 文 献}

1 ) Yusuf, A., Sodiq, A., Giwa, A., Eke, J., Pikuda, O., De Luca, G., Luque Di Salvo, J., Chakraborty, S., 2020. A review of emerging trends in membrane science and technology for sustainable water treatment. Journal of Cleaner Production 266, 121867.

2 ) 入谷英司, 片桐誠之, 杉山悠生, 2011. 希薄コロイドの定速お よび定圧精密濾過における膜閉塞特性. 化学工学論文集 37(4), 323-326.

3 ) Iritani, E., Katagiri, N., 2016. Developments of blocking filtration model in membrane filtration. KONA Powder and Particle Journal 33, 179-202.

4 ) American Society for Testing and Materials, 2007. Standard 
test method for silt density index (SDI) of water, D19.08 on membranes and ion exchange materials. ASTM D4189-07.

5 ) White, D.A., 1996. The interpretation of the SDI for water solids content using the filtration equation. Process Safety and Environmental Protection 74(2), 137-140.

6 ) Park, C., Kim, H., Hong, S., Choi, S.I., 2006. Variation and prediction of membrane fouling index under various feed water characteristics. Journal of Membrane Science 284(1-2), 248-254.

7 ) Park, C., Kim, H., Hong, S., Lee, S., Choi, S.I., 2007. Evaluation of organic matter fouling potential by membrane fouling index. Water Science \& Technology: Water Supply 7(5-6), 27-33.

8 ) 松本幹治, 古市光春, 中村一穂, 新田見匡, 2009. 膜ろ過プロ セスにおける修正 SDI による水質評価．膜 34(2)，94-103.

9 ) Alhadidi, A., Kemperman, A.J.B., Schippers, J.C., Wessling, M., van der Meer, W.G.J., 2012. SDI: is it a reliable fouling index? Desalination and Water Treatment 42(1-3), 43-48.

10) Habib, M., Habib, U., Memon, A.R., Amin, U., Karim, Z., Khan, A.U., Naveed, S., Ali, S., 2013. Prediction colloidal fouling of tap water by silt density index (SDI): Pore blocking in a membrane process. Journal of Environmental Chemical Engineering 1(1-2), 33-37.

11) Shippers, J.C., Verdouw, J., 1980. The Modified Fouling Index, a method of determining the fouling characteristics of water. Desalination 32, 137-148.

12) Boerlage, S.F.E., Kennedy, M.D., Dickson, M.R., El-Hodali, D.E.Y., Schippers, J.C., 2002. The modified fouling index using ultrafiltration membranes (MFI-UF): characterization, filtration mechanisms and proposed reference membrane. Journal of Membrane Science 197(1-2), 1-21.

13) Khirani, S., Ben Aim, R., Manero, M.H., 2006. Improving the measurement of the Modified Fouling Index using nanofiltration membranes (NF-MFI). Desalination 191(1-3), $1-7$.

14) Iritani, E., Katagiri, N., Sawada, D., 2018. Simultaneous evaluation of mechanism and degree of fouling from limited flux decline data in dead-end microfiltration. Journal of Chemical Engineering of Japan 51(6), 507-517.

15) Tow, E.W., Lienhard, J.H., 2017. Unpacking compaction: Effect of hydraulic pressure on alginate fouling. Journal of
Membrane Science 544, 221-233.

16) Cao, D.Q., Jin, J.Y., Wang, Q.H., Song, X., Hao, X.D., Iritani, E., Katagiri, N., 2020. Ultrafiltration recovery of alginate: membrane fouling mitigation by multivalent metal ions and properties of recycled materials. Chinese Journal of Chemical Engineering 28, 2881-2889.

17）原田美冬, 古澤和輝, 鈴木祐麻, 新苗正和, 和田善成, 市村重 俊，2020. 下水の再利用を目的とした統合的膜処理システムにお ける逆浸透膜のアルギン酸によるファウリングとカルシウムイオ ンの役割. 水環境学会誌 43(6), 165-173.

18) Lee, H., Ahmad, R., Kim, J., 2020. Alginate to simulate biofouling in submerged fluidized ceramic membrane reactor: Effect of solution $\mathrm{pH}$ and ionic strength. Bioresource Technology 302, 122813.

19) Teng, J., Chen, Y., Ma, G., Hong, H., Sun, T., Liao, B.Q., Lin, H., 2020. Membrane fouling by alginate in polyaluminum chloride (PACl) coagulation/microfiltration process: Molecular insights. Separation and Purification Technology 236, 116294.

20) Hermans, P.H., Bredée, H.L., 1936. Principles of the mathematical treatment of constant-pressure filtration. Journal of the Society of Chemical Industry 55T, 1-4.

21) Grace, H.P., 1956. Structure and performance of filter media. II. Performance of filter media in liquid service. AIChE Journal 2(3), 316-336.

22) Shirato, M., Aragaki, T., Iritani, E., 1979. Blocking filtration laws for filtration of non-Newtonian fluids. Journal of Chemical Engineering of Japan 12(2), 162-164.

23) Hermia, J., 1982. Constant pressure blocking filtration laws Application to power-law non-Newtonian fluids. Transactions of the Institution of Chemical Engineers 60 (3), 183-187.

24) Iritani, E., Katagiri, N., Sugiyama, Y., Yagishita, K., 2007. Analysis of flux decline behaviors in filtration of very dilute suspensions. AIChE Journal 53(9), 2275-2283.

25）片桐誠之, 2014. 微生物試料の分離における膜利用. 膜 39(1), $14-20$.

26) Iritani, E., Katagiri, N., Yamashita, Y., 2017. Effect of membrane morphology on rising properties of filtration resistance in microfiltration of dilute colloids. AIChE Journal $63(8), 507-517$.

\section{[論 文 要 旨]}

限られた期間のごくわずかな膜濾過データで求まるファウリング指標から, 濾過の全挙動を推算する手法 を提案する。閉塞濾過理論に基づき, 膜閉塞特性とファウリング指標 FMI（Fouling Mechanism Index）と の関係を明らかにすることで，濾過挙動の推算に必要となる閉塞特性值を求める方法を確立した。定圧条件 の膜濾過における, 濾過速度および濾液量の経時変化を推算したところ, 膜の初期特性と閉塞特性に基づく 計算值は実験值の挙動を概ね表していた。本手法は，試料の濃度や分離膜の種類といった滤過条件，および 膜の目詰まりやケークの形成といったファウリング機構によらず広く適用可能なことも確認された。したが つて, 実際の膜処理条件に合わせて, 滤過試験を限られた時間で行い, 膜特性と FMI を求めることで，膜洗 浄や膜交換の時期の決定にも繋がる滤過挙動の推算值を得ることができる。

$$
\text { キーワード : 膜滤過 ; 膜ファウリング ; ファウリング指標 ; ファウリング機構 ; 閉塞滤過 }
$$


